The Editor,

fournal of Glaciology

SIR,

\section{Evidence of the Kuwaiti oil fires in the Dasuopu glacier ice core, central Himalaya}

During the Persian Gulf War in 1990-91, more than 740 oil wells in Kuwait were sabotaged (Ferek and others, 1992), and more than 600 wells were set afire. The world, and in particular the Middle East, was left with one of the largest man-made environmental disasters, producing a pronounced impact on regional and global climate and environment (Bakan and others, 1991). Oil fire products during the Persian Gulf War migrated over the Northern Hemisphere. The smoke aerosol from long-range transport of Kuwaiti oil fires was observed in Japan (Okada and others, 1992), Pakistan (Limaye and others, 1991), Hawaii (Lowenthal and others, 1992), as well as Wyoming in the U.S.A. (Deshler and Hofmann, 1992).

In summer 1997, a $15 \mathrm{~m}$ ice core, covering the period 1988-97, was collected from $7000 \mathrm{~m}$ a.s.l. on a relatively flat portion of Dasuopu glacier $\left(28^{\circ} 23^{\prime} \mathrm{N}, 85^{\circ} 44^{\prime} \mathrm{E}\right)$ on the northwest margin of Mount Xixiabangma in the central Himalaya. Detailed methods of ice-core sampling and chemical analysis are described by Kang and others (2000), along with a discussion of monsoon and dust signals in the core. Profiles of $\delta^{18} \mathrm{O}$ and major-ion $\left(\mathrm{Ca}^{2+}, \mathrm{NO}_{3}{ }^{-}\right.$and $\left.\mathrm{SO}_{4}{ }^{2-}\right)$ concentrations against water-equivalent depth are shown in Figure 1. In general, variations of $\mathrm{SO}_{4}{ }^{2-}$ are in agreement with those of $\mathrm{Ca}^{2+}$ and $\mathrm{NO}_{3}{ }^{-}$in the ice core, mainly reflecting dust input from central Asia (Kang and others, 2000). The highest $\mathrm{SO}_{4}{ }^{2-}$ concentration, $730.7 \mathrm{ppb}$ (marked by an arrow in Figure 1), in the core is recorded during early 1991 . The lowest $\mathrm{SO}_{4}{ }^{2-}$ concentration is $6.1 \mathrm{ppb}$, and mean $\mathrm{SO}_{4}{ }^{2-}$ is $122.9 \mathrm{ppb}$ ( $\operatorname{std}$ dev. 132.2). $\mathrm{Ca}^{2+}$ and $\mathrm{NO}_{3}{ }^{-}$concentrations during early 1991 do not have anomalous peaks. Thus, the $1991 \mathrm{SO}_{4}{ }^{2-}$ is unique and appears not to be related to dust deposition.

In June 1991, the explosive eruption of Mount Pinatubo, Philippines, injected an estimated $(18 \pm 2) \times 10^{6} \mathrm{t}$ of $\mathrm{SO}_{2}$ directly into the atmosphere (Krueger and others, 1995). The volcanic aerosol mass was dispersed gradually in the global atmosphere, covering the entire Earth by mid-1992 (Hitchman and others, 1995). Pinatubo volcanic signals were identified in South Pole snow, which occurred from early or mid-1992 to mid-1994 (Cole-Dai and Mosley-Thompson, 1999). Though we cannot confirm when volcanic aerosol was transported to the Dasuopu core site, it was probably later than June 1991. However, the highest $\mathrm{SO}_{4}{ }^{2-}$ value in the Dasuopu core is recorded in early 1991 (Fig. 1). Thus, we consider that the 1991 spike of $\mathrm{SO}_{4}{ }^{2-}$ concentration is not related to the Pinatubo eruption.

We assume that the $\mathrm{SO}_{4}{ }^{2-}$ peak in 1991 in the Dasuopu ice core is related to the Kuwaiti oil fire products during the Persian Gulf War. Firstly, the Kuwaiti oil wells were set afire

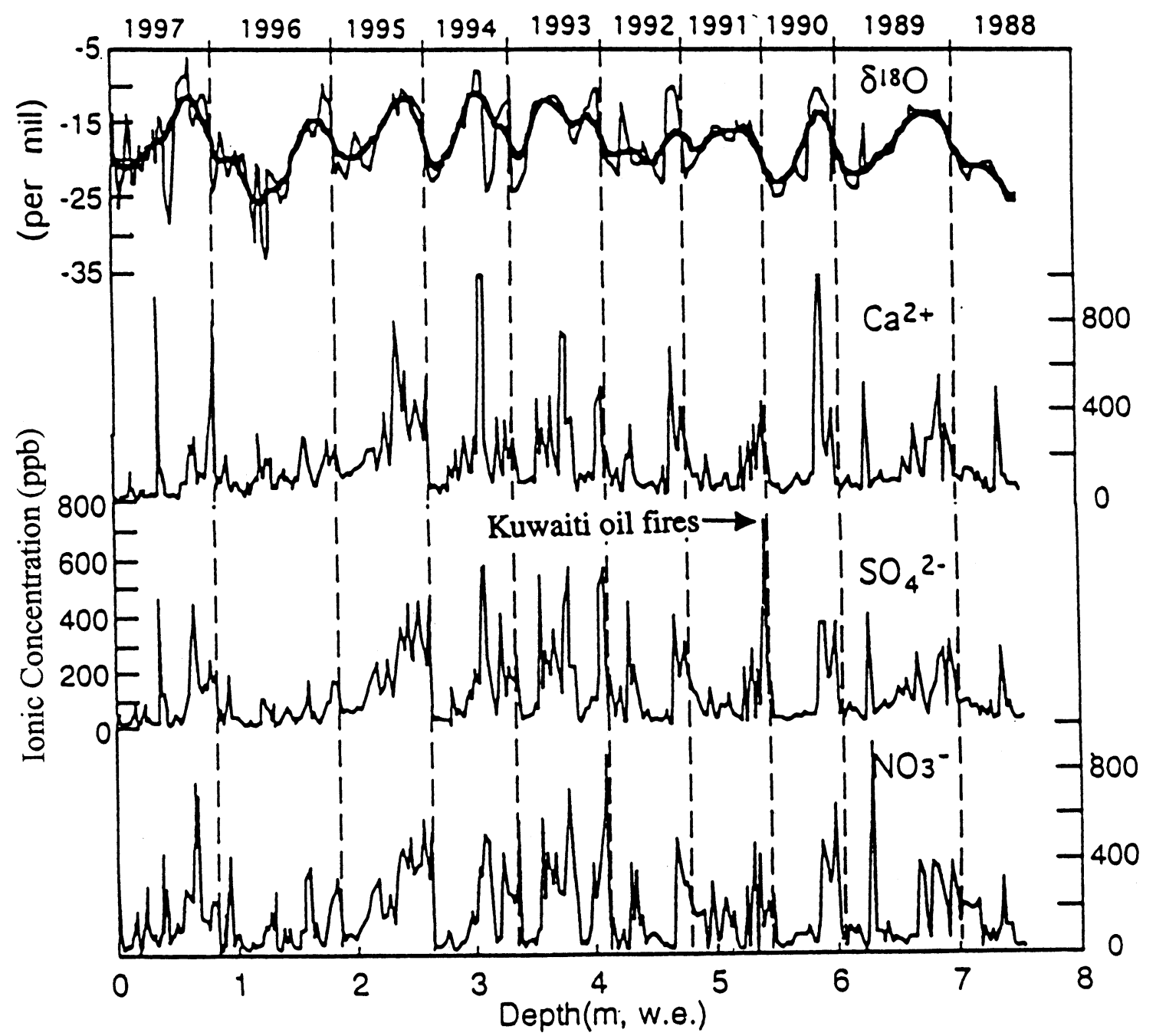

Fig. 1. Depth profiles of $\delta^{18} O$ and ionic concentrations with depth (water equivalent) in the Dasuopu ice core. Dating was performed by counting seasonal peaks of $\delta^{18} \mathrm{O}$ and major ions. The coarse solid line is a weighted smoothing (5 points smoothing). Dashed lines indicate annual layers. 
in early 1991 (Ferek and others, 1992) and the aerosol smoke from oil fires was transported to the Himalayan region by a southern westerly jet, which only took 1-2 days (Bodhaine and others, 1992). Secondly, measurements of organic matter in the same core indicate that concentrations of some organic compounds from petroleum residues were higher during 1988-92 than in 1997 (Xie and others, 2000). Thirdly, chemical analysis of smoke plumes from the Kuwaiti oil fires shows that $\mathrm{SO}_{2}$ concentrations are 1-2 orders of magnitude higher than $\mathrm{NO}_{\mathrm{x}}$, and $\mathrm{SO}_{4}{ }^{2-}$ is the dominant species among major ions in smoke plumes (Ferek and others, 1992). These points suggest that pollutants from Kuwaiti oil fires were transported to Dasuopu glacier by the westerly jet and recorded in snow at $7000 \mathrm{~m}$ a.s.l. in the Himalaya. Thus, ice-core records from the Himalaya provide a unique opportunity to recover pollutant signals and reconstruct environmental changes in the past.

\section{ACKNOWLEDGEMENTS}

This research is supported by the Chinese Academy of Sciences (KZCX2-305, KZ951-A1-402, KZCX2-301/108, KZCX1-10-02), the NKBRSF Project of China (G1999043400) and the National Nature Science Foundation of China (49871022).

\section{Laboratory of Ice Core and \\ Cold Regions Environment, \\ Cold and Arid Regions Environment and \\ Engineering Research Institute, CAS, \\ Lanzhou 730000, People's Republic of China}

\section{KANG SHICHANG ${ }^{*}$ QIN DAHE}

\author{
* Institute for Quaternary \\ and Climate Studies, \\ University of Maine, \\ Orono, Maine 04469-5790, U.S.A.
}

Laboratory of Ice Core and

Cold Regions Environment,

XIE SHUCHENG

Cold and Arid Regions Environment and

Engineering Research Institute, CAS,

Lanzhou 730000, People's Republic of China

10 September 2001

\section{REFERENGES}

Bakan, S. A. and 16 others. 1991. Climate response to smoke from the burning oil well in Kuwait. Nature, 351 (6325), 367-371.

Bodhaine, B. A., J. M. Harris, J. A. Ogren and D. J. Hofmann. 1992. Aerosol optical properties at Mauna Loa observatory: long-range transport from Kuwait? Geophys. Res. Lett., 19(6), 581-584.

Cole-Dai, J. and E. Mosley-Thompson. 1999. The Pinatubo eruption in South Pole snow and its potential value to ice-core paleovolcanic records. Ann. Glaciol., 29, 99-105.

Deshler, T. and D. J. Hofmann. 1992. Measurements of unusual aerosol layers in the upper troposphere over Laramie, Wyoming, in the spring of 1991: evidence for long-range transport from the oil fires in Kuwait. Geophys. Res. Lett., 19 (4), 385-388.

Ferek, R. J., P.V. Hobbs, J. A. Herring and K. K. Laursen. 1992. Chemical composition of emissions from the Kuwait oil fires. 7. Geophys. Res., 97(D13), 14,483-14,489.

Hitchman, M. H., M. McKay and C. R. Trepte. 1995. A climatology of stratospheric aerosol. 7. Geophys. Res., 99(D10), 20,698-20,700.

Kang Shichang, C. P. Wake, Qin Dahe, P. A. Mayewski and Yao Tandong. 2000. Monsoon and dust signals recorded in Dasuopu glacier, Tibetan Plateau. F. Glaciol., 46(153), 222-226.

Krueger, A. J. and 6 others. 1995. Volcanic sulfur dioxide measurements from the total ozone mapping spectrometer instruments. 7. Geophys. Res., 100 (D7), 14,057-14,076.

Limaye, S. S., V. E. Suomi, C. Velden and G. Tripoli. 1991. Satellite observations of smoke from oil fires in Kuwait. Science, 252(5012), 1536-1539.

Lowenthal, D. H., R. D. Borys and J. C. Chow. 1992. Evidence for longrange transport of aerosol from the Kuwait oil fires to Hawaii. F. Geophys. Res., $97(\mathrm{D} 13), 14,573-14,580$.

Okada and 6 others. 1992. Kuwait soot overJapan. Nature, 355(6356), 120.

Xie Shucheng, Yao Tandong, Kang Shichang, Duan Keqin, Xu Baiqin and L. G. Thompson. 2000. Geochemical analysis of a Himalayan snowpit profile: implication for atmospheric pollution and climate. Organic Chem., 31(1), 15-23. 